\title{
Cost Analysis of Vocational School Education Unit in Mechanical Engineering Expertise Competency by Using Activity-Based Costing Method
}

\author{
Bz. Septeiyawan Abdullah*, Didik Nurhadiyanto \\ Graduate School Yogyakarta State University, Yogyakarta, Indonesia \\ *Corresponding author: bzsepteiyawan.2017@student.uny.ac.id \\ Received November 04, 2019; Revised December 12, 2019; Accepted January 02, 2020
}

\begin{abstract}
This study aims to determine: 1) the percentage of cost allocation for activities in SMK N 3 Yogyakarta and SMK Muhammadiyah 3 Yogyakarta and 2) the comparison of the education cost unit of each student, level, and year in the competency of mechanical engineering expertise in SMK N 3 Yogyakarta and SMK Muhammadiyah 3 Yogyakarta. The location of this research was in two vocational schools that have mechanical engineering expertise competencies in Yogyakarta City, i.e., SMK N 3 Yogyakarta and SMK Muhammadiyah 3 Yogyakarta. The object of this research was the cost unit of education at SMK N 3 Yogyakarta and SMK Muhammadiyah 3 Yogyakarta. This research was a quantitative descriptive study. The interview and documentation were utilized as data collection techniques. The data analysis used an activity-based costing method. The results of this study indicated that: (1) the percentages of cost allocation for each activity at SMK N 3 Yogyakarta are teaching and learning activities 64\%, students' activities 10\%, infrastructure management activities $8 \%$, school administration activities 7\%, school management activities $4 \%$, non-HR school development activities $4 \%$, and HR school development activities $2 \%$. Meanwhile, the percentages of cost allocation at SMK Muhammadiyah 3 Yogyakarta are teaching and learning activities 35\%, school administration 34\%, school management activities 12\%, infrastructure management activities 7\%, student activities 7\%, HR school development activities $4 \%$ and non-HR school development activities $1 \%$. (2) the unit cost of education for each mechanical engineering expertise competency student, level, and year at SMK N 3 Yogyakarta for the 10th grade is Rp10.342.809, the 11th grade is Rp9.255.154, and the 12th grade is Rp11.120.704. Whereas at SMK Muhammadiyah 3 Yogyakarta for the 10th grade is Rp 12.244.183, the 11th grade is Rp11.598.900, and the 12th grade is Rp13.738.086.
\end{abstract}

Keywords: cost unit of education, vocational school of mechanical engineering competency, and activity-based costing

Cite This Article: Bz. Septeiyawan Abdullah, and Didik Nurhadiyanto, "Cost Analysis of Vocational School Education Unit in Mechanical Engineering Expertise Competency by Using Activity-Based Costing Method." American Journal of Educational Research, vol. 8, no. 1 (2020): 1-6. doi: 10.12691/education-8-1-1.

\section{Introduction}

The era of technological advancements and the current development now affects all aspects and fields of human life, including in the field of education. Educational development is basically as important as economic development [1]. It means that the urgency of increasing education is the same as increasing economic development. Therefore, education becomes an area that must be continuously studied and developed. A good education will generate competent human resources so that it will help the development of the country's economy. Therefore, the implementation of education in Indonesia must be planned carefully and conducted as well as possible, so that it can produce the competent next generation.

Implementing education certainly has an education system. A good education system is built with good planning. The government and parties related to education must plan carefully the implementation of the education process. Educational planning can be used to achieve educational goals more effectively and efficiently and can be used to build systems in the appropriate strategies [2]. Education management is aimed at ensuring the quality and competitiveness of education and its relevance to the needs and/or conditions of the community [3]. However currently, the quality and competitiveness of education in Indonesia are still low. It can be observed from the curriculum that is not suitable with the characteristics of the Indonesian nation, the quality of school graduates that are not in line with community expectations, incompetent teachers, facilities and infrastructure that are less supportive, high gaps in the implementation of education among regions in Indonesia, as well as other problems. The implementation of education in Indonesia has not applied effectively and efficiently, so it is necessary to increase efficiency [4]. 
Based on data from reference [5] viewed from the level of education, the Open Unemployment Rate for vocational school is the highest among other education levels, which is $8,92 \%$. Whereas for primary school is $2,67 \%$, secondary school is $5,18 \%$, university $6,31 \%$, senior high school is 7, 19\%, and Diploma I-III is 7, 92\%. It indicates that vocational school in this era, which is expected to be able to create graduates ready for work, still does not have the competitiveness in meeting the needs or conditions of society.

Discussing the quality of education is certainly inseparable with the cost or tuition fee. The tuition fee is one of the important components of instrumental input in the administration of education [6]. The tuition fee is an essential factor in quality assurance and the quality of education. Although the cost of education is not the only factor in the successful implementation of education, without adequate cost, the good quality of education will not be able to be implemented [7].

Schools need information about cost as a consideration in implementing the cost-efficiency. Accuracy in determining the costs need to determine whether the activities conducted by schools have been carried out effectively and efficiently or not. Furthermore, a cost analysis can also be used as material to analyze which items occur cost inefficiency. Therefore, schools as educational institutions need to know the information about the cost of education clearly as a basis for decision making. At present, determining the cost of education in schools still uses the traditional method. Supposedly, schools as a non-profit institution must consider carefully the determination of the education budget. Determination of inappropriate education costs will cause over-costing or under-costing [8]. Accurate cost determination certainly helps the government in determining the amount of operational assistance that will be budgeted for each student.

Activity-Based Costing is an accounting system that focuses on organizational activities and the collection of costs based on the underlying nature [9]. The ActivityBased Costing method can be used to determine the number of costs that schools must charge to students based on the activities conducted. This information will be useful to know whether the fees charged to students are insufficient, sufficient or excessive. Activity-Based Costing provides comprehensive and detailed cost information [10]. Activity-Based Costing is a powerful and profitable approach for non-profit organizations such as educational institutions because it provides better and accurate information [11]. Activity-Based Costing can link product costs with product information [12]. It means the application of Activity Based Costing in schools will be able to reveal on how each students' activities in each grade and the package of expertise, the time required, and the costs absorbed for each activity at a different competency package and level.

Based on pre-research results, the calculation of the cost of education at school is still very simple. The determination of the cost of education for each student in vocational schools in Yogyakarta, both in state and private school, are equal for each level. In fact, the activities conducted by students in each package of expertise are different especially in the engineering expertise program.
The tuition fee for SMK N 3 Yogyakarta for the 10th 12th grade students is Rp. 75,000/month. Whereas, the tuition fee for the 10th -11th grade of SMK Muhammadiyah 3 Yogyakarta is Rp. 300,000/month and 12th grade is Rp. 250,000/month.

Equitable costs can lead to over costing and under costing. Over costing means that the cost is too high so that a product or service produced requires fewer resources but it has a high cost per unit. Under costing means that the determination of costs is too low so that the costs determined are lower than the real resources needed to produce the product or service [8]. Schools need cost information as one of the bases for implementing efficiency. Therefore, this research needs to be done to uncover the comparison of the calculation results of the education cost for each student and level, especially the engineering expertise program at SMK N 3 Yogyakarta and SMK Muhammadiyah 3 Yogyakarta by using the Activity Based Costing method.

\section{Research Methodology}

This study aims to determine: 1) the percentage of cost allocation for activities in SMK N 3 Yogyakarta and SMK Muhammadiyah 3 Yogyakarta and 2) the comparison of unit education costs for each student, level and year in the mechanical engineering expertise competency at SMK N 3 Yogyakarta and SMK Muhammadiyah 3 Yogyakarta. The object of this research was the unit cost of education at SMK N 3 Yogyakarta and SMK Muhammadiyah 3 Yogyakarta. This research was a quantitative descriptive study. Data collection techniques utilized documentation and interviews.

The interview was conducted to identify costs and activities, while documentation was conducted to collect secondary data in the form of RKAS, lesson hours, number of rooms, and room area. The activity-based costing method is utilized as the data analysis. Activitybased costing is an activity-based cost analysis system to meet the needs of personnel in decision making both strategic and operational [13]. The Activity-Based Costing method consists of several stages, namely: a) identifying activities and attributes of the activity, b) charging costs to the activity, c) collecting costs in the cost pool, d) determining and calculating cost drivers and e) determining unit costs [14].

\section{Results and Discussion}

The initial stage, the identification of activities and attributes of activities, is known that the activities in the school are divided into seven types, namely: teaching and learning activities, student activities, school administration activities, school management activities, non-HR school development activities, human resource school development activities, and infrastructure management activities. These activities are then classified into three activity groups namely: result producing activities, result contributing activities, and support activities. The seven activities are also focused on 2 groups, namely the main activity and supporting activities for the process for 
calculating unit costs for each student, level and year in the mechanical engineering expertise competency. Table 1 shows a list of activities and ways of charging costs.

Table 1. List of Activities and How to Load them

\begin{tabular}{|c|c|c|}
\hline Activities & Activity groups & Charging Cost \\
\hline \multicolumn{3}{|c|}{ The main activity } \\
\hline $\begin{array}{c}\text { Teaching and } \\
\text { learning activities }\end{array}$ & $\begin{array}{c}\text { Result producing } \\
\text { activities }\end{array}$ & $\begin{array}{c}\text { Direct tracing, Driver, } \\
\text { Tracing, Allocation }\end{array}$ \\
\hline Student activities & $\begin{array}{c}\text { Result producing } \\
\text { activities }\end{array}$ & $\begin{array}{c}\text { Direct tracing, Driver, } \\
\text { Tracing, Allocation }\end{array}$ \\
\hline \multicolumn{3}{|c|}{ Supporting activities } \\
\hline $\begin{array}{c}\text { School } \\
\text { administration } \\
\text { activities } \\
\end{array}$ & Support activities & Allocation \\
\hline $\begin{array}{c}\text { School management } \\
\text { activities }\end{array}$ & $\begin{array}{c}\text { Result contributing } \\
\text { activities }\end{array}$ & Allocation \\
\hline $\begin{array}{c}\text { Non-HR school } \\
\text { development } \\
\text { activities } \\
\end{array}$ & Support activities, & Driver tracing \\
\hline $\begin{array}{c}\text { Human resource } \\
\text { school development } \\
\text { activities }\end{array}$ & Support activities & Driver tracing \\
\hline $\begin{array}{c}\text { Infrastructure } \\
\text { management } \\
\text { activities } \\
\end{array}$ & $\begin{array}{c}\text { Result contributing } \\
\text { activities }\end{array}$ & Driver tracing \\
\hline
\end{tabular}

\subsection{The Percentage of Cost Allocation for Each Activity}

In the second stage, the imposition of costs on activities, the amount of costs allocated to each activity is identified. It is comprehended that the total amount of cost at SMK N 3 Yogyakarta is Rp.17,776,177,875 with the allocation of costs for each activity: Rp. 11,398,217,305 for Teaching and Learning activities, Rp. 1,696,500,555 for Student activities, Rp. 298,120,996 for School Administration activity, Rp 735,773,094 for School Management activity, Rp 775,597,895 for Non-HR School Development Activities, Rp 362,761,000 for HR School Development activities, and Rp. 509,207,029 for Infrastructure Development Activities activities. Meanwhile, in SMK Muhammadiyah 3 Yogyakarta the total amount of cost is Rp. 14,054,024,973 with the allocation of costs for each activity: Rp4,845,018,493 for Teaching and Learning activities, Rp 941,757,622 for Student activities, Rp. 4,750,792 .904 for School Administration activities, Rp 1,731,725,184 for School Management activities, Rp 194,235,000 for Non-HR School Development Activities, Rp. 557,000,000 for HR School Development activities, and Rp. 1,033,495,769 for Infrastructure Development activities.

The percentage of the cost allocation for SMK N 3 Yogyakarta and SMK Muhammadiyah 3 Yogyakarta can be observed in Figure 1 and Figure 2. In both vocational schools, it is known that teaching and learning activities require the greatest allocation. It is because teaching and learning activities are the most essential activities in schools. At SMK N 3 Yogyakarta, the difference in the amount of allocation of costs consumed by teaching and learning activities is very significant compared to other activities. However, it does not occur in SMK Muhammadiyah 3 Yogyakarta because the School Administration Activities are almost equivalent to the Teaching and Learning Activities. The smallest percentage of cost allocation at SMK N 3 Yogyakarta is the Development Activity of HR Schools while at SMK Muhammadiyah 3 Yogyakarta is the non-HR Development Program. It indicates that those two activities do not require/consume a lot of costs.

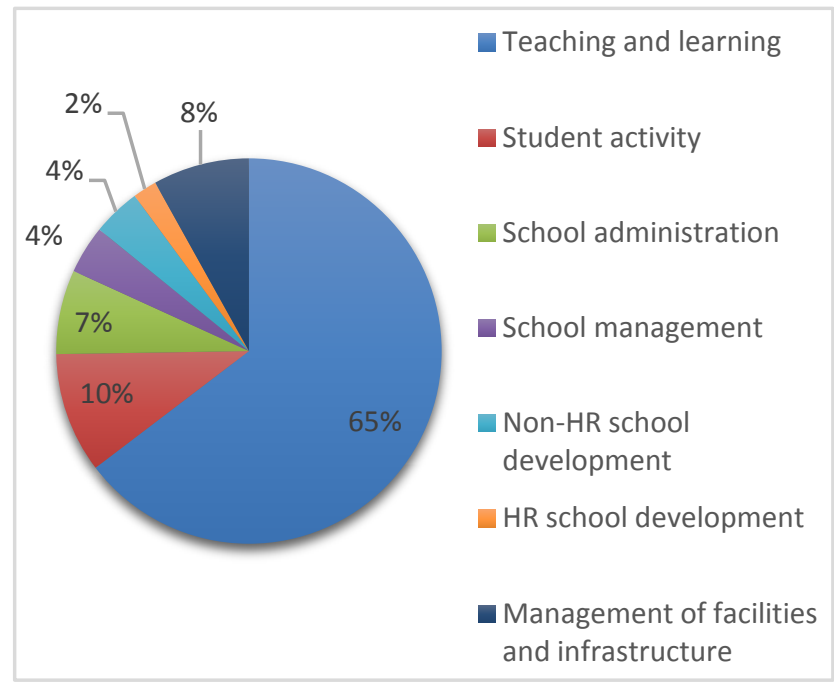

Figure 1. Percentage of Cost Allocation for Each Activity of SMK N 3 Yogyakarta

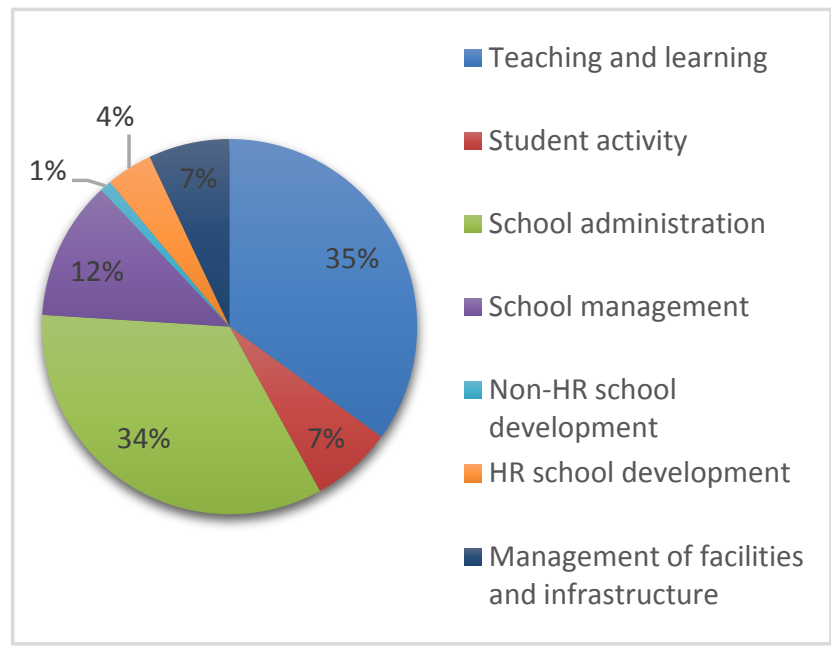

Figure 2. Percentage of Cost Allocation for Each Activity of SMK Muhammadiyah 3 Yogyakarta

\subsection{Unit Cost of Education for Each Student, Level and Year in Mechanical Engineering Competency}

In the process of calculating the education unit costs for each student and level of competence in mechanical engineering expertise, the third stage namely collecting costs in the cost pool to facilitate the process of charging costs that have a common driver is done. Costs that have been charged to teaching and learning activities and students are then identified according to their characteristics. Then, costs that have a common driver are classified in the activity cost pool. Table 2 and Table 3 indicate the classification of costs in teaching and learning activities to the activity cost pool. Table 4 and Table 5 show the classification of costs in student activities into an activity cost pool. 
Table 2. Classification of Costs in Teaching and Learning Activities SMK N 3 Yogyakarta

\begin{tabular}{|c|l|c|}
\hline No & Rincian & Biaya yang Dibebankan \\
\hline 1 & Charging costs for maintenance of mechanical competence tools & Rp80.283.500 \\
\hline 2 & Teaching and Learning (KBM) activity cost pool between competencies & Rp283.502.050.150 \\
\hline 3 & Teaching and Learning activity cost pool between study groups & Rp1.895.289.860 \\
\hline 4 & Activity cost pool for all students & Rp877.982.000 \\
\hline 5 & Teaching and Learning activity cost pool for all students & Rp143.410.000 \\
\hline 6 & Teaching and Learning activity cost pool specifically for 12th grade & Rp166.284.000 \\
\hline 7 & Teaching and Learning activity cost pool specifically for 10th and 11th grade & Rp9.747.558.124 \\
\hline 8 & Teaching and Learning activity cost pool specifically for 11 and 12th grade & Rp15.528.576.274 \\
\hline 9 & Teaching and Learning activity cost pool based on lesson hours & \\
\hline Total & &
\end{tabular}

Table 3. Classification of Costs in Teaching and Learning Activities at SMK Muhammadiyah 3 Yogyakarta

\begin{tabular}{|c|l|c|}
\hline No & Rincian & Biaya yang Dibebankan \\
\hline 1 & Procurement of practice materials & Rp75.000.000 \\
\hline 2 & Teaching and Learning activity cost pool between competencies & Rp552.300.000 \\
\hline 3 & Teaching and Learning activity cost pool between study groups & Rp919.231.016 \\
\hline 4 & Teaching and Learning activity cost pool for all students & Rp157.900.000 \\
\hline 5 & Teaching and Learning activity cost pool specifically for 10th grade & Rp125.000.000 \\
\hline 6 & Teaching and Learning activity cost pool specifically for 11th grade & Rp5.46.0000.000 \\
\hline 7 & Teaching and Learning activity cost pool specifically for 12th grade & Rp11.487.063.545 \\
\hline 8 & Teaching and Learning activity cost pool based on lesson hours & \\
\hline Total & & \\
\hline
\end{tabular}

Table 4. Classification of Costs in Student Activities at SMK N 3 Yogyakarta

\begin{tabular}{|c|l|c|}
\hline No & Rincian & biaya yang dibebankan \\
\hline 1 & Conducting extracurricular activities & Rp233.865.600 \\
\hline 2 & Conducting commemoration of national holiday activity (Peringatan Hari Besar Nasional or PHBN) & Rp29.375.000 \\
\hline 3 & Student Achievement Award (1st place in the best UN score) & Rp4.200.000 \\
\hline 4 & Activity cost pool students specifically for $10^{\text {th }}$ grade & Rp219.122.500 \\
\hline & Activity cost pool students specifically for $12^{\text {th }}$ grade & Rp148.520.000 \\
\hline 5 & Activity cost pool for students in all students & Rp1.612.518.501 \\
\hline 6 & Conducting extracurricular activities & Rp2.247.601.601 \\
\hline Total & & \\
\hline
\end{tabular}

Table 5. Classification of Costs in Student Activities at SMK Muhammadiyah 3 Yogyakarta

\begin{tabular}{|c|l|c|}
\hline No & Rincian & biaya yang dibebankan \\
\hline 1 & Extracurricular activities & Rp24.000.000 \\
\hline 2 & Achievement coaching & Rp10.000.000 \\
\hline 3 & Mubaligh Hijrah & Rp78.000.000 \\
\hline 4 & Student Activities & Rp106.530.000 \\
\hline 5 & Activity cost pool students specifically for $10^{\text {th }}$ grade & Rp111.525.000 \\
\hline 6 & Activity cost pool students specifically for $12^{\text {th }}$ grade & Rp2.226.909.774 \\
\hline 7 & Activity cost pool for students in all students & Rp2.566.964.774 \\
\hline
\end{tabular}

Next, the calculation of the unit cost of education for each student and level of competence in mechanical engineering expertise needs to do the fourth step, which is to calculate the cost driver tariff first. After calculating the cost driver, the next step is to calculate the activity driver rate for each level and expertise competency. The formula for calculating the activity driver rate is as follows:

$$
\begin{aligned}
& \text { Activity Driver Rate (ADR) } \\
& =\text { Cost Driver } \times \text { Activity Driver. }
\end{aligned}
$$


Table 6. Determination of unit costs for Expertise Competency Education in Mechanical Engineering at SMK N 3 Yogyakarta

\begin{tabular}{|c|c|c|c|c|c|c|c|c|}
\hline \multirow{2}{*}{\multicolumn{2}{|c|}{\begin{tabular}{l|l} 
No & Activity \\
Teaching and Learning Activity
\end{tabular}}} & \multirow[t]{2}{*}{$\begin{array}{c}\text { Cost Driver } \\
\text { Tariffs }\end{array}$} & \multicolumn{2}{|r|}{$10^{\text {th }}$ grade } & \multicolumn{2}{|r|}{$11^{\text {th }}$ grade } & \multicolumn{2}{|r|}{$12^{\text {th }}$ grade } \\
\hline & & & AD & ADR & AD & ADR & AD & ADR \\
\hline 1 & $\begin{array}{l}\text { Charging Costs for Maintenance of } \\
\text { Mechanical Competency Tools }\end{array}$ & - & & Rp9.986.497 & & Rp9.161.167 & & Rp8.335.836 \\
\hline 2 & $\begin{array}{l}\text { Teaching and Learning Activity Cost } \\
\text { Pool between Competencies }\end{array}$ & Rp203.562.799 & $1 / 3$ & Rp67.854.266 & $1 / 3$ & Rp67.854.266 & $1 / 3$ & Rp67.854.266 \\
\hline 3 & $\begin{array}{l}\text { Teaching and Learning Activity Pool } \\
\text { Cost Between Study Groups }\end{array}$ & Rp4.717.503 & 4 & Rp18.870.010 & 4 & Rp18.870.010 & 4 & Rp18.870.010 \\
\hline 4 & $\begin{array}{l}\text { Teaching and Learning Activity Cost } \\
\text { Pool for All Students }\end{array}$ & Rp1.103.838 & 121 & Rp133.564.399 & 111 & Rp122.526.019 & 101 & Rp111.487.639 \\
\hline 5 & $\begin{array}{l}\text { Teaching and Learning Activity Cost } \\
\text { Pool Specifically for } 10^{\text {th }} \text { grade }\end{array}$ & Rp1.429.938 & 121 & Rp173.022.511 & & & & \\
\hline 6 & $\begin{array}{l}\text { Teaching and Learning Activity Cost } \\
\text { Pool Specifically for } 12^{\text {th }} \text { grade }\end{array}$ & Rp1.261.100 & & & & & 101 & Rp127.371.145 \\
\hline 7 & $\begin{array}{l}\text { Teaching and Learning Activity Cost } \\
\text { Pool Specifically for } 10^{\text {th }} \text { and } 11^{\text {th }} \\
\text { grade }\end{array}$ & Rp123.950 & 121 & Rp14.997.934 & 111 & Rp13.758.436 & & \\
\hline 8 & $\begin{array}{l}\text { Teaching and Learning Activity Cost } \\
\text { Pool Specifically for } 10^{\text {th }} \text { and } 11^{\text {th }} \\
\text { grade }\end{array}$ & Rp150.756 & & & 111 & Rp16.733.929 & 101 & Rp15.226.368 \\
\hline 9 & $\begin{array}{l}\text { Teaching and Learning Activity Cost } \\
\text { Pool Based on Lesson Hours }\end{array}$ & Rp72.462 & 8968 & Rp649.837.208 & 8968 & Rp649.837.208 & 8968 & Rp649.837.208 \\
\hline \multicolumn{9}{|c|}{ Students Activity } \\
\hline 1 & Conducting Extracurricular Activities & Rp202.131 & 121 & Rp24.457.854 & 111 & Rp22.436.544 & & \\
\hline 2 & $\begin{array}{l}\text { Conducting commemoration of } \\
\text { national holiday activity (Peringatan } \\
\text { Hari Besar Nasional or PHBN) }\end{array}$ & Rp17.108 & 121 & Rp2.070.108 & 111 & Rp1.899.024 & 101 & Rp1.727.941 \\
\hline 3 & $\begin{array}{l}\text { Student Achievement Award for } \\
\text { National Examination }\end{array}$ & Rp210.000 & & & & & 4 & Rp840.000 \\
\hline 4 & $\begin{array}{l}\text { Activity Cost Pool for Specifically } \\
\text { Student } 10^{\text {th }} \text { grade }\end{array}$ & Rp356.877 & 121 & Rp43.182.121 & & & & \\
\hline 5 & $\begin{array}{l}\text { Activity Cost Pool for Specifically for } \\
\text { Student } 12^{\text {th }} \text { grade }\end{array}$ & Rp265.214 & & & & & 101 & Rp26.786.643 \\
\hline 6 & $\begin{array}{l}\text { Student Activity Cost Pool for All } \\
\text { Students }\end{array}$ & Rp939.149 & 121 & Rp113.637.006 & 111 & Rp104.245.518 & 101 & Rp94.854.029 \\
\hline & Total Cost & & & Rp1.251.479.915 & & Rp1.027.322.121 & & Rp1.123.191.086 \\
\hline Nur & er of Students each level & & & 121 & & 111 & 101 & 101 \\
\hline Stuc & nt Unit Costs each Year & & & Rp10.342.809 & & Rp9.255.154 & & Rp11.120.704 \\
\hline Mo & hly Student Unit Costs & & & Rp861.901 & & Rp771.263 & & Rp926.725 \\
\hline
\end{tabular}

Table 7. Determination of Expertise Competency Education Unit Cost in Mechanical Engineering at SMK Muhammadiyah 3 Yogyakarta

\begin{tabular}{|c|c|c|c|c|c|c|c|c|}
\hline \multirow[t]{2}{*}{ No } & \multirow[b]{2}{*}{ ing and Learning Activities } & \multirow[t]{2}{*}{$\begin{array}{c}\text { Cost Driver } \\
\text { Tariff }\end{array}$} & \multicolumn{2}{|c|}{$10^{\text {th }}$ grade } & \multicolumn{2}{|c|}{$11^{\text {th }}$ grade } & \multicolumn{2}{|c|}{$12^{\text {th }}$ grade } \\
\hline & & & AD & ADR & AD & ADR & AD & ADR \\
\hline 1 & Procurement of Practice Materials & - & & Rp4.413.793 & & Rp5.977.011 & & Rp5.609.195 \\
\hline 2 & $\begin{array}{l}\text { Teaching and Learning Activity Cost Pool } \\
\text { between Competencies }\end{array}$ & Rp464.845.705 & $1 / 3$ & Rp154.948.568 & $1 / 3$ & Rp154.948.568 & $1 / 3$ & Rp154.948.568 \\
\hline 3 & $\begin{array}{l}\text { Teaching and Learning Activity Pool Cost } \\
\text { Between Stufy Groups }\end{array}$ & Rp11.751.064 & 2 & Rp23.502.128 & 3 & Rp35.253.191 & 3 & Rp35.253.191 \\
\hline 4 & $\begin{array}{l}\text { Teaching and Learning Activity Cost Pool } \\
\text { for All Students }\end{array}$ & Rp807.760 & 48 & Rp38.772.486 & 65 & Rp52.504.408 & 61 & Rp49.273.367 \\
\hline 5 & $\begin{array}{l}\text { Teaching and Learning Activity Cost Pool } \\
\text { Special } 10^{\text {th }} \text { grade }\end{array}$ & Rp413.351 & 48 & Rp19.840.838 & & & & \\
\hline 6 & $\begin{array}{l}\text { Teaching and Learning Activity Cost Pool } \\
\text { Specifically for } 11^{\text {th }} \text { grade }\end{array}$ & Rp314.070 & & & 65 & Rp20.414.573 & 61 & Rp19.158.291 \\
\hline 7 & $\begin{array}{l}\text { Teaching and Learning Activity Cost Pool } \\
\text { Specifically for } 12^{\text {th }} \text { grade }\end{array}$ & Rp1.312.849 & & & & & 61 & Rp80.083.799 \\
\hline 8 & $\begin{array}{l}\text { Teaching and Learning Activity Cost Pool } \\
\text { Based on Lesson Hours }\end{array}$ & Rp51.900 & 4484 & Rp232.717.598 & 6726 & Rp349.076.396 & 6726 & Rp349.076.396 \\
\hline \multicolumn{9}{|c|}{ Student Activities } \\
\hline 1 & Extracurricular activities & 30769,23077 & 48 & Rp1.476.923 & 65 & Rp2.000.000 & & \\
\hline 2 & Achievement coaching & Rp510.638 & 2 & Rp1.021.277 & 3 & Rp1.531.915 & 3 & Rp1.531.915 \\
\hline 3 & Mubaligh Hijrah & Rp8.787 & 48 & Rp421.793 & 65 & Rp571.178 & 61 & Rp536.028 \\
\hline 4 & Students activity & Rp68.541 & 48 & Rp3.289.982 & 65 & Rp4.455.185 & 61 & Rp4.181.019 \\
\hline 5 & $\begin{array}{l}\text { Activity Cost Pool for Special Student } 10^{\text {th }} \\
\text { grade }\end{array}$ & Rp278.874 & 48 & Rp13.385.969 & & & & \\
\hline 6 & $\begin{array}{l}\text { Activity Cost Pool for Special Student } \\
\text { Class XII }\end{array}$ & Rp311.522 & & & & & 61 & Rp19.002.863 \\
\hline \multirow[t]{2}{*}{7} & Student Activity Cost Pool for All Students & Rp1.956.863 & 48 & Rp93.929.410 & 65 & Rp127.196.077 & 61 & Rp119.368.626 \\
\hline & Total Cost & & & Rp587.720.764 & & Rp753.928.502 & & Rp838.023.261 \\
\hline \multicolumn{2}{|c|}{ Number of Students Each level } & & & 48 & & 65 & & 61 \\
\hline \multicolumn{2}{|c|}{ Student Unit Costs Each Year } & & & Rp12.244.183 & & Rp11.598.900 & & Rp13.738.086 \\
\hline \multicolumn{2}{|c|}{ Student Unit Costs Each Month } & & & Rp1.020.349 & & Rp966.575 & & Rp1.144.841 \\
\hline
\end{tabular}


The total of the activity driver rate is then used to calculate the unit cost of education for each student, level and year by dividing the total activity driver rate by the number of students in each expertise competency level. Table 6 and Table 7 show the calculation of competency unit education costs for mechanical engineering expertise at SMK N 3 Yogyakarta and SMK Muhammadiyah 3 Yogyakarta.

\section{Conclusion}

Activities in Vocational Schools are divided into seven activities, namely teaching and learning activities, student activities, school administration activities, school management activities, non-HR school development activities, human resource school development activities, and infrastructure management activities. The percentages of cost allocation for each activity after the calculation at SMK N 3 Yogyakarta are 64\% for teaching and learning activities, $10 \%$ for student activities, $8 \%$ for infrastructure management activities, $7 \%$ for school administration activities, school management activities by $4 \%$, non-HR school development activities by $4 \%$, and $2 \%$ for HR school development activities. Whereas, at SMK Muhammadiyah 3 Yogyakarta the percentages are 35\% for teaching and learning activities, 34\% for school administration activities, $12 \%$ for school management activities, 7\% for infrastructure management activities, 7\% for student activities, 4\% for human resource school development activities, and $1 \%$ for non-HR school development activities.

Based on the calculation of costs in mechanical engineering expertise, it is known that the unit costs of education for each student, level, and year at SMK N 3 Yogyakarta are Rp10.342.809 for the 10th grade, Rp9.255.154 for the 11th grade and Rp11.120.704 for the 12th. Whereas, that the unit costs of education at SMK Muhammadiyah 3 Yogyakarta are Rp12.244.183 for the 10th grade, Rp11.598.900 for the 11th grade, and Rp13.738.086 for the 12th grade. The total unit cost of the 10th grade at SMK N 3 Yogyakarta and the total unit cost of the 12th grade at SMK Muhammadiyah 3 Yogyakarta are greater than other grade levels. It is because the costs collected in the activity cost pool for special learning activities in the 10th grade at SMK N 3 Yogyakarta and the 12th grade at SMK Muhammadiyah 3 Yogyakarta are very high.

\section{References}

[1] Mulyono, “Konsep Pembiayaan Pendidikan”, Ar-Ruzz Media, Yogyakarta, 2010, 22

[2] Matin, “Dasar-Dasar Perencanaan Pendidikan”, PT Raja Grafindo Persada, Jakrata, 2013, 16.

[3] Pemerintah Indonesia, Peraturan Pemerintah Republik Indonesia No. 17 Tahun 2010 tentang Pengelolaan dan Penyelenggaraan Pendidikan. Lembaran Negara RI Tahun 2010 No. 17, Sekretariat Negara, Jakarta, 2010. Retrieved from:

http://luk.staff.ugm.ac.id/atur/PP17-2010Lengkap.pdff.

[4] OECD, Survei Ekonomi Indonesia, Maret 2015. [Online]

Available: https://www.oecd.org/economy/Overview-Indonesia2015-Bahasa.pdf.

[5] Widayanti, N., "KeadaanKetenagakerjaan Indonesia Februari 2018”, BadanPusat Statistik, Jakarta, Indonesia, No.42/05/Th XXI, May 07, 2018. Retrieved from: http://www.turc.or.id/wpcontent/uploads/2018/06/BPS_Berita-Resmi-Statsitik_KeadaanKetenagakerjaan-Indonesia-Februari-2018.pdf.

[6] Supriadi, D., "Satuan Biaya Pendidikan Dasar dan Menengah", PT Remaja Rosdakarya, Bandung, 2004, 3.

[7] Mulyono, “Konsep Pembiayaan Pendidikan”, Ar-Ruzz Media, Yogyakarta, 2010, 5.

[8] Horngren, C. T., Datar, S. M., \& Foster, G., “Akuntansi Biaya Jilid 1. (Terjemahan P.A. Lestari)”, PT Gelora Aksara Pratama, Jakarta, 2008, 161. (Edisi asli diterbitkan tahun 2006 oleh Pearson Education Inc. Upper Saddle River, New Jersey).

[9] Raiborn, C. A \& Kinny, R. K., “Akuntansi Biaya: Dasar dan Pengembangan. (Terjemahan Rahmat Hilman)”, Salemba Empat, Jakarta, 2011, 150. (Edisi asli diterbitkan tahun 2009 oleh Cengage Learning Asia Pte Ltd 5 Shenton Way Singapore).

[10] Maelah, R., Amir, A. M., Ahmad, A., et al., Cost per Students Using ABC Aproach. International Proceedings of Economics Develompment and Research, Vol 9, 7, 40-45, 2011.

[11] Tapanjeh, A. M., Activity-Based Costing Approach to Handle the Uncertainty Costing of Higher Educational Institutions: Perspective from an Academic College. Journal of King Abdul Aziz University, 2008, 2, 29-57.

[12] Akyol, D. E, Tuncen, G., \& Bayhan, G. M., A Comparative Analysis of Activity-Based Costing and Traditional Costing. International Scholarly and Scientific Research \& Innovation, 2007, Vol 1, 3, 136-139.

[13] Mulyadi, “Activity Based-cost System”, UPP STIM YKPN, Yogyakarta, 2007, 48.

[14] Hansen, D. R. \& Mowen, M. M., “Akuntansi Manajerial”, (Terjemahan Deny Arnos Kwary), Salemba Empat, 2009, 176-185. (Edisi asli diterbitkan tahun 2007 oleh Cengage Learning Asia Pte Ltd. 5 Shenton Way Singapore). 